IJTC

Ilomata International Journal of Tax \& Accounting

P-ISSN: 2714-9838; E-ISSN: 2714-9846

Vol. 1 No. 2 March 2020 Pp : 66-73

https://www.ilomata.org/index.php/ijtc

\title{
Expectations and Standards for Accounting Professions and Implications in the Learning Pattern in Industrial 4.0
}

\author{
Iman Supriadi, KusumaAdi Rahardjo ,Miya Dewi Suprihandari \\ Accounting major Faculty of Economics, STIE Mahardhika Surabaya \\ iman@stiemahardhika.ac.id
}

Submitted : Jan 3th 2020 Revised : Feb 14th 2020 Published : March 30 th 2020

\begin{abstract}
This paper talks about the impact from the commercial transformation 4.0 on accounting scientific research and accounting education and learning patterns. The commercial transformation can be turbulent and make development throughout accounting scientific research and designs from accounting knowing or education and learning in the future. To ensure that the adjustment needs from accounting professionals and trainees that are taking accounting research studies are required to have the ability to instantly adapt to the instructions from modifications in market 4.0 that are currently operating. It's anticipated that accounting will modification to "huge information" based upon accounting innovation, consisting of automation from journaling and monetary coverage. Besides, using Synthetic Knowledge will be huge in analysis of monetary declarations and examining the behavior from companies or businesses. Consequently, this impacts the knowing patterns from representing trainees that will place much more focus on grasping info systems regarding the real truth from the business globe.
\end{abstract}

Keywords: Industry 4.0, Internet of Things, the accounting profession, Artificial Intelligence, accounting learning patterns.

\section{INTRODUCTION}

The fast advance from wise innovation has resulted in the development of Market 4. 0 . This development includes the 'internet from points which is anticipated to offer huge info accessibility with limitless interconnectivity (Kagermann, 2015). This offers a method where people, info, and interaction innovation expand with each other (Pisaniello J \& Burritt RL, Tingey-Holyoak J, 2014). This evolution was followed by the emergence of cloud-based computing, large-scale data or known as big data, genetic experiments, changes in neurotechnology that are possible for humans to further maximize the role of the brain (World Economic Community, 2016) while Deloitte (Deloitte, 2017) portrays industry 4.0 so that the integration of digital information from several sources and places that start on manual activities in doing business is easier and more effective(Aisyah et al., 2019; Amelia et al., 2019; Hartasetiadi \& Sidik, 2019).

Market 4.0 initially began in Germany and after that complied with by various other nations such as the US, Japan, and China. Nevertheless, it's expected that Market 4. 0 will result in considerable reductions in labor-intensive people, which consequently can result in high unemployment prices, particularly amongst grads around the world (Grey J \& Hughes M, 2016). This is because the Market 4. 0 atmosphere will tend to get rid of a regular job and many more jobs (Deloitte, 2015). As a consequence, Industry 4.0 will revolutionize the industry (Davies R, 
Expectations and Standards for Accounting Professions and Implications in the Learning Pattern in Industrial 4.0

Supriadi, Rahardjo, Suprihandari

2015) so that current jobs no longer exist in the next 50 years. The country echoes the use of high computerized technology in manufacturing or manufacturing work. The word "industry 4.0" appeared around 2011 at the Hannover Fair, and in 2013 at the same place, a working group was led by Siegfried Dais (Robert Bosch GmbH) and Henning Kagermann a German Academy of Sciences and Engineering. The design principles used are divided into four things, namely Interconnection, Information transparency, Technical Assistance, and Decentralized Decisions(Andrayanti, 2019; Kumala, 2019; Meilani \& Pandoyo, 2019; Sinaga \& Sidik, 2019).

The World Economic Forum foresees that Industry 4.0 is probably going to bring about a total deficit of more than 5 million employments in 15 created and creating nations, and Malaysia is no special case right now. The result is where the Malaysian government may need to confront rising joblessness and salary disparity, combined with a contracting shopper based business. The most influenced in the Industry 4.0 condition are the middle of the road abilities employments (Cormier D and Magnan M, 2015). The information that most undergrad bookkeeping understudies will be utilized in the middle of the road abilities occupations raises concerns whether these alumni will have the option to verify work after graduation. Along these lines, to guarantee the employability of graduates, educating, and learning exercises of bookkeeping, understudies should be acclimated to the desires for businesses of bookkeeping graduates in Industry 4.0 (Cooper B, 2015). As a result, given the likely employment domain, accounting students must be prepared to meet Industry 4.0 demand.

During the industrial revolution, 4.0 is projected to have relevant and admirable effects on several factors, especially on products, supply chains, customers, and workers. Elements of workers who are either trapped directly or indirectly will be reviewed in this paper. The accountant is a career that is trapped in a direct way in it, which of course, has a disruptive impact on how an accountant carries out the job he carries, not only has to adjust to increasing his ability to face the 4.0 industrial revolution that has been initiated. From Bloomberg.com data in 2016, developments in the order of the company were witnessed by market capitalization throughout the last decade (2006 and 2016). Around the year 2016, large companies were dominated by technology-based companies and produced information technology products. It can be analyzed if the capitalization of the first number company in 2016, namely Apple, is 38\% greater than Exxon Mobil in 2006, which means that the development of technology companies is $2 \mathrm{x}$ that of companies operating in the sector not only in information technology.

According to Gerd Leonhard in 2015, which predicts that globally, the era of the digital industry will get rid of 1 to 1.5 million jobs from the period of 2015 to 2025 due to the fact the human element can be replaced by engine power. Also, data obtained from the US Department of Labor predicts $65 \%$ of school students in the world will face jobs or careers that never exist now, which means there will be new obstacles and new experiences in work and types of work in the world of work. Cutler and Lewis (2016) said that in the UK alone, technology has the role of removing 800,000 jobs. However, in addition to the positive side, the digitalization period has the potential to increase the new workforce of around 2.1 million to 2025, which means there are career choices and varied occupations. Also, mechanization and digitalization can reduce the strength of carbon emissions by 26 billion metric tons (World Economic Community, 2016).

From the description of the character and concentration of industry 4.0, it is clear that the career sequence of accountants needs to follow the fast rhythm and rhythm of the revolution. Moving - moving eroded or can survive on that development. Until the accountant will face the sequence that is the admit to noise signal where the accountant has understood the 
Expectations and Standards for Accounting Professions and Implications in the Learning Pattern in Industrial 4.0

Supriadi, Rahardjo, Suprihandari

existence of intimidation and will be prepared to take advantage of the moment of intimidation so that it can be taken part of, changes take hold which is where the accountant has felt there is a development in his activities but feels no need to take a stand because it has not disrupted the "status quo", the inevitable transformation, that is, accountants have changed because the capacity "status quo" has been disturbed by the existence of this revolution and accountants must carry out the rapid transformation of development and the best way is only for several factors seen as needing and adapting to the new normal namely the transformation of accountants 'careers in detail by the demands of the new mode of industry 4.0 or accountants' careers will be lost if they cannot adjust to that development.

Industry 4.0 is characterized as another period that constructs and extends the effect of digitalization in new and sudden manners; which can likewise be portrayed as the rise of "physical-digital frameworks" that include altogether new capacities and network for people and machines (Davies, 2015; Liu and Xu, 2017). It is trusted that this period will influence work helplessness (Seele P, 2016), particularly among graduates. Work recently done by people will to a great extent be supplanted by computerization (Christ KL, Burritt RL, 2015). Their exploration found that somewhat less than half of the employments in the US are presented to the danger of being inefficient because Industry 4.0 because robots can perform routine assignments as well as refined obligations outside daily practice. Their discoveries suggest that while Industry 4.0 gives a chance to the individuals who are prepared to acknowledge it, this period likewise presents extraordinary difficulties for the conventional calling, including the bookkeeping calling is no special case.

In the bookkeeping calling, bookkeepers can get ready for another time by bringing issues to light, building information through expert improvement and proceeding with training, empowering the advancement of abilities in new contestants, and working together with different experts (Cooper, 2015). Representing framework mix in Industry 4.0 is probably going to be at an elevated level, and association with neighborhood bookkeeping issues in the business condition will be at a significant level of availability (Kagermann, 2014). Industry 4.0 is relied upon to impact bookkeeping rehearses because bookkeepers can acquire information that beforehand couldn't be gotten progressively, improve information quality through more noteworthy exactness and practicality in improving information proficiency and information confirmation, just as other dynamic objectives. Moreover, this period is relied upon to expand the believability and pertinence of revealing (Burritt and Christ, 2016). To put it plainly, bookkeepers will have the chance to be less engaged with robotized activities and spotlight more on enormous picture systems, for example, asset productivity. In any case, bookkeepers need involvement with innovation to stay in solid interest.

For newcomers to the bookkeeping calling, proficient bodies can help scholastics and colleges in giving pertinent educational plans to graduates who may need to battle with the Industrial 4.0 time since it includes new computerized network. Regularly, researchers and colleges react by changing existing course content or presenting new courses and instructing strategies to defeat new conditions. The activity is planned to expand the employability of their alumni. This is conceivable through putting resources into innovation for functional experience and furnishing involvement in pretending in the Industry 4.0 situation. Accordingly, working with proficient bodies and bookkeepers can help scholastics and colleges in conveying courses appropriate for bookkeeping graduates to be significant in the Industrial 4.0 time. In this 
Expectations and Standards for Accounting Professions and Implications in the Learning Pattern in Industrial 4.0

Supriadi, Rahardjo, Suprihandari

manner, bookkeeping graduates must be prepared at colleges to become qualified workers who can conquer the groundwork for confronting Industry 4.0 (Wübbeke J and Conrad B, 2015).

Portfolios in instructive innovation have gotten more differing than any other time in recent memory in light of the fact that different kinds of programming are presently accessible to help scholastics in making educating and learning encounters all the more convincing. The digitalization of training has given more options in contrast to scholastics in their educating and learning strategies (Burrit and Roger. 2016). Apparently, this gives a chance to scholastics to devise methodologies to scatter their insight to understudies, in a way that is significant and pragmatic, with the goal that graduates will have the option to adjust and stay popular in reality (Cormier D and Magnan M, 2015). Be that as it may, the instructing and learning procedure must be successful when scholastics and colleges know the desires for business visionaries bookkeeping graduates in the coming time.

\section{METHOD}

In the examination procedure methodology, a lot of general and explicit logical strategies that are psychological are utilized. This sort of research is qualitative, where in contemplating the hypothetical position and the ebb and flow condition of bookkeeping tasks, the utilization of hypothetical speculation techniques, gathering, correlation investigation and combination, perception, and verifiable methodologies are actualized. Improved meaning of the association and practice of bookkeeping tasks utilizing the strategies for acceptance and finding, gathering, hypothetical speculations. Unmistakable technique is utilized to give an outline to speak to the aftereffects of the investigation.

\section{RESULT AND DISCUSSION}

From the accountant's position description, there are obstacles and impacts on accountants' careers, including where technology changes change business as relevant as many assets that are in the form of "technology" and not in physical form, requiring less HRT counted, including accounting staff, where the company has no idea "Place" or "premises" because it is controlled through the "virtual office" and most recently about the market steps and steps to sell through the "market place" or "online store" all of which will just be towards the point of equilibrium or new equilibrium which will later create own standards.

In the next five years, where $5 \mathrm{G}$ technology in telecommunications devices has been fully adopted, high-speed internet connections per second and human hardware have also been connected both with IoT or IoP, which will change the role of accountants replaced by AI (Artificial Intelligence) technology. As well as robotics in doing the fundamental accountant's job, namely recording transactions, processing transactions, separating operations, mechanizing the work of the balance sheet as well as analyzing the financial balance independently without any human involvement. The following self-managed fundamentals role of accountant scheme, which, of course, increases the efficiency and effectiveness of work, and the results are immediately found at that time (real-time). Many companies have improved this because it has been supported by the existence of standardization of financial control processes and standardization of the ideal information scheme architecture and in accordance with the demands of the fourth generation industry until important competencies are needed for accountants after that the potential for data analysis, follow changes in information technology and update style leadership. 
Expectations and Standards for Accounting Professions and Implications in the Learning Pattern in Industrial 4.0

Supriadi, Rahardjo, Suprihandari

Furthermore, the effect is that accountants and accounting firms will be "forced" to improve mobile applications so they can connect data directly from handheld devices, tablets, and virtual reality. The balance sheet audit is carried out on a real-time basis where regulators and auditors automatically pull the required data directly from the scheme and sensors attached to operational work so that the transparency and accuracy of the data made can be justified. If the accountant does not have the ideal skills in information technology, another career can replace the role of the accountant, so that it can be mentioned that info technology is a core requirement that needs to be studied and understood by the accountant. Taken from the December 2016 edition of the International Edition of Accounting and Business Magazine, Roger Leonard Burrit and Katherine Christ said four steps that accountants need to take in the face of the industrial revolution 4.0 namely :

a. Awareness. If the industrial revolution gave birth to new opportunities or opportunities. This opportunity is growing new businesses that never existed initially. Hence, the example of Germany as the initiating country has $80 \%$ of companies ready to implement industrial revolution 4.0 or China that understands if development is needed on the knowledge factor and targets $60 \%$ investment in this field. Not only these two countries but many countries are already in the initial step of disseminating information, which after that, will grow deeper to run with the whole revolution 4.0.

b. Education. Regulators or the government and education activists are required to be able to make a curriculum related to changes in digital connectivity, such as coding training, information management between several programs, and unequal basis or implementation of real-time accounting intended for all departments and company organizations as holders stock.

c. Career Development. Increase the career capacity of accountants and programs that support their development by doing online presentation exercises or face to face discussions (face to face discussion) and assessing their effects on the career capabilities of accountants in the future.

d. Application of high standards. So the accountant is required to have optimal control over the data created, where data or physical information is generally obtained under the responsibility of several engineers (engineer) so that the fabric of work between the accountant and engineer must go hand in hand so that the data and accounting information are well maintained.

The four steps in the development of the role of accountants during the 4.0 industry revolution described above should have been initiated at the beginning of the evaluation process on campus or college where the curriculum and method of evaluation must also be in accordance with the actual business world now and in the future. Until the campus or college needs to look for and use evaluation methods that improve the most important factor, namely human literacy where the important concentration is to improve students' cognitive abilities, so they can think seriously and systemically because human literacy can play a good role when referring to "humanity"; communication and design. Until the evaluation focused on factors namely skills in terms of leadership and working together in teamwork, agility and cultural maturity (cultural agility) so that students with some background can work in environments that are not the same either domestically or outside the environment state and entrepreneurship counted in it "social entrepreneurship" which means entrepreneurship that can contribute to 
Expectations and Standards for Accounting Professions and Implications in the Learning Pattern in Industrial 4.0

Supriadi, Rahardjo, Suprihandari

social development with sustainability and on target. Each student must possess the following point of fundament.

Aoun (2017) said that to arrive at an efficient evaluation factor. By the desired direction, it is needed a thematic study that unites between the university environment and the real work world (base learning project). This thematic study can give a factual description to students about the latest state of the world of work and all the obstacles encountered. Northeastern (2014) indicates the implementation of practical work or apprenticeship activities in the company, so one of them is an inefficient reference evaluation. Referring to the formulation of the KKNI Team (Indonesian National Qualification Framework) Evaluation Directorate (2015), college or university graduates must be prepared (not only human literacy) to have data literacy potential, namely reading, analyzing and using info in big data format (big data) and technological literacy. Technology literacy means understanding the work steps of a machine, application of technology, artificial intelligence, and engineering principles. Until the combined human literacy, data and technology can answer the obstacles of the industrial revolution 4.0.

So it's evident that the obstacles of the industrial revolution of the past could change the overall role and standard of current accountants. The development of the accountant's role includes providing views or opinions about the data. Accountants are required to be able to identify questions on data, statistical analysis, tracking data quality and interpretation of data processing results, acting as an adviser, either as a business advisor, specialist, or acting as a business partner. Can work together in the struggle for technology that includes data fraud, work with robots or the like and become a trainer in the section of artificial intelligence and accountant careers grow not only in financial factors but will extend to non-financial reporting factors and data security in cyberspace (cyber security).

Accountants from the industrial revolution are not becoming "bookkeepers" but are expanding into something new that cannot be genuinely touched by financial factors. Exploration of new things naturally led to the specialization that did not yet exist at this time. The specialty here, if you look at the information above, increases to a new part of work that demands different abilities and abilities as well because it is needed to be able to see the strength of development in a short or long period. Intermediate between the real world of work and the academic world should be bridged for further analysis and research in which research results can be used to provide a solution that is informative and can be applied later in the teaching and learning process in the campus, college, and career.

\section{CONCLUSION AND RECOMMENDATION}

Industry 4.0 gave birth to several new things that would affect the careers of accountants and students who were studying accounting. Industrial digitalization and real-time transactions can monitor quickly and quickly the performance of organizations or companies both in manufacturing, supply chains, and customers. Accountant careers are expected to be able to adjust to this, and more importantly, campuses and universities must change and revolutionize the evaluation process to be able to follow the fast rhythm of changes in information technology. Further studies and analysis are needed to summarize the ways and evaluations of accountants' careers and accounting students so that the accounting stigma becomes "bookkeeper" more full and has more valuable value by the characteristics and concentration of industry 4.0 where the role and benefits become more varied. It is desirable to have the results of analysis and research 
Expectations and Standards for Accounting Professions and Implications in the Learning Pattern in Industrial 4.0

Supriadi, Rahardjo, Suprihandari

that can produce competent graduates or scholars and can act optimally in technological development.

\section{REFERENCE}

Aisyah, W. U. N., Salim, F., \& Sofyan, M. (2019). The Influence of Service Quality and Price on the Interest of Commuterline KRL Passengers. Ilomata International Journal of Management, 1(1), 13-18.

Amelia, S., Salamah, H., \& Sofyan, M. (2019). Effect of Marketing Strategy and Service Quality Against the Decisions of Parents. Ilomata International Journal of Management, 1(1), 31-37.

Andrayanti, I. (2019). Internal Control Analysis towards the Accounts Receivable Accounting System at STIAMI Institute. Ilomata International Journal of Tax and Accounting, 1(1), 1-11.

Bloomberg (2016).World largest list company. 24 August 2016

Burrit, leonarddan Katherine Christ (2016). International Edition of Accounting and Business magazine p.43-46.Desember 2016

Burrit, Roger. 2016. Industry 4.0 and environmental accounting: a new revolution? . Asian Journal of Sustainibility and Social Responsiblity. 12 Desember 2016

Christ KL, Burritt RL (2015) Material flow cost accounting: a review and agenda for future research. J Clean Prod 108: 1378-1389

Cormier D, Magnan M (2015) The economic relevance of environmental disclosure and its impact on corporate legitimacy: An empirical investigation. Bus StratEnvt 24(6):431-450

Cooper B (2015) Class of 2025: The Future Finance Professional. In: Evans E, Burritt R, Guthrie J (eds) Future Proofing the Profession: Preparing Business Leaders and Finance Professionals for 2025, vol 6, Academic Leadership Series Chartered Accountants Australia and New Zealand/RMIT University., pp 81-87

Cutler, Steven \& Lewis, Mark (2016).Industry 4.0 and manufacturing ecosystem. March 2016

Davies R (2015) Industry 4.0. Digitalisation for productivity and growth, Briefing for the European Parliament (PE 568.337) September 2015. European Parliamentary Research Service

Deloitte (2015) Industry 4.0 Challenges and solutions for the digital transformations and use as expontial technologies, Delloite AG, Zurich

Deloitte (2017) Forces of change: Industry 4.0. www.deloitte.com/insights

Gray J, Hughes M (2016) Insight. Industry 4.0: It's The Future, But We've Been There Before. Digital Transformation.Hitashi Consulting, Dallas

Hartasetiadi, R., \& Sidik, M. (2019). Analysis on Exchange of Information (EOI) to Increase the Quality of Investigation on Beneficial Owner Dispute (BO) According to Verdict of Tax Court from 2013 to 2015 in Directorate of Objection and Appeal. Ilomata International Journal of Tax and Accounting, 1(1), 26-34.

Jaenudin, Edi (2018). Financial reporting in the digital age. February 2018

Kagermann H (2015) Change Through Digitization-Value Creation in the Age of Industry 4.0.

In: Albach H, Meffert H, Pinkwart A, Reichwald R (eds) Management of Permanent Change. Springer Fachmedien, Wiesbaden, pp 23-45

Kumala, R. (2019). Factors That Influence MSME Taxpayers' Willingness to Pay Tax After the Implementation of the Government Rules Number 23 of 2018. Ilomata International Journal of Tax and Accounting, 1(1), 18-25.

Leonhard, gerd (2017).The 7 keys future principles of digital transformation. May 2017

Martani, Dwi (2016). Accountants in the era of the industrial revolution 4.0. September 2016. 
Expectations and Standards for Accounting Professions and Implications in the Learning Pattern in Industrial 4.0

Supriadi, Rahardjo, Suprihandari

Meilani, M., \& Pandoyo, P. (2019). The Influence of Account Receivable for Inventory of Income before Tax. Ilomata International Journal of Tax and Accounting, 1(1), 35-40.

Learning Directorate. Ministry of Higher Education. Indonesian National Qualification Framework Team; 2016

Seele P (2016) Digitally unified reporting: how XBRL-based real-time transparency helps in combining integrated sustainability reporting and performance control. J Clean Prod 136(Part A):65-77

Sinaga, J., \& Sidik, M. (2019). Analysis of Increase in Non-Taxable Income (NTI) in relation with Implementation of Equality Principles and Taxation Base Principles. Ilomata International Journal of Tax and Accounting, 1(1), 12-17.

Tingey-Holyoak J, Pisaniello J, Burritt RL (2014) The need for Engineering Accounting: Identifying current and future demand and supply. Report to the Institute of Chartered Accountants in Australia, Sydney

World economic forum (2016).Carbon waste management.www.weforum.org/reports

Wübbeke J, Conrad B (2015) Industrie 4.0: Will German Technology Help China Catch Up with the West? China Monitor 23:1-10 